\title{
A Study on Variability, Character Association and Path Analysis for Pod Yield in French Bean (Phaseolus vulgaris L.)
}

\author{
A. Panda ${ }^{1 *}$, A. Paul ${ }^{2}$ and P. Mohapatra ${ }^{3}$ \\ ${ }^{1 \& 2}$ Dept. of CIHAB, Palli Siksha Bhavana (Institute of Agriculture),Visva-Bharati, Sriniketan,West Bengal (731 236), India \\ ${ }^{3}$ Dept. of Vegetable Science, O.U.A.T., Bhubaneswar, Odisha (751 003), India
}

\section{Article History}

Manuscript No. AR1506

Received in $19^{\text {th }}$ December, 2015

Received in revised form $28^{\text {th }}$ January, 2016

Accepted in final form $4^{\text {th }}$ February, 2016

\section{Correspondence to}

*E-mail: amitabhp70@gmail.com

\section{Keywords}

French bean, genotypes, variability, yield, path analysis

\begin{abstract}
Field experiments were conducted during two seasons i.e., rabi 2011-12 and 2012-13 at four locations of district Nayagarh of Odishato evaluate 28 genotypes of french bean for various morpho-physiological characters. The variance analysis showed that most of the traits showed moderate and moderate to high values for GCV and PCV suggesting high scope for selection. The estimates of heritability showed that most of the traits showed either moderate to high and high heritability. The characters such as green pod length, basal internodal diameter, days to $1^{\text {st }}$ green pod picking, plant height, basal internodal length, green pod width, number of pods plant ${ }^{-1}$, days to $50 \%$ flowering, number of secondary branches plant ${ }^{-1}$ showed very high amount of heritability. The simultaneous studies of variability, heritability and genetic advance showed that due emphasis should be given on traits such as plant height, number of primary branches plant $^{-1}$, number of secondary branches plant $t^{-1}$, basal intermodal length, number of pods plant $^{-1}$ during selection process. The correlation studies revealed that pod yield plant ${ }^{-1}$ was positively correlated with number of pods plant ${ }^{-1}$, green pod length, number of secondary branches plant ${ }^{-1}$, number of primary branches plant ${ }^{-1}$ and negatively with days to $50 \%$ flowering, days to $1^{\text {st }}$ green pod picking. The path analysis showed that direct selection for number of pods plant ${ }^{-1}$, single pod weight, and green pod length will increase pod yield plant ${ }^{-1}$ in french bean. The study revealed that due emphasis should be given on number of pods plant ${ }^{-1}$, plant height and number of secondary branches plant ${ }^{-1}$ during selection process for development of superior genotypes.
\end{abstract}

\section{Introduction}

French bean (Phaseolus vulgaris L. $2 \mathrm{n}=2 \mathrm{X}=22$ ), family Fabaceae, also known as snap bean, kidney bean, garden bean or string bean is the most important leguminous vegetable crop (Singh, 1999) grown for its tender fleshy green pods, shelled green seeds and also dry bean (Rajmash). It originated from Central America and Peruvian Andes in South America (Kaplan, 1965). It was introduced to India from Europe during $17^{\text {th }}$ century. The statistics with respect to this crop is very poor owing to its short duration and cultivation in limited areas. However, as per FAO estimates, it is cultivated in an area of $28 \mathrm{mha}$, with annual production of $20 \mathrm{mt}$., with average productivity of $0.72 \mathrm{tha}^{-1}$ in world (FAO STAT, 2008). In India, it is mainly grown in Jharkhand, Maharashtra, Karnataka, West Bengal, Himachal Pradesh, Odisha, Uttar Pradesh, Punjab, Haryana, Andhra Pradesh, Tamil Nadu in an area of 0.15 mha with annual production of $0.42 \mathrm{mt}$ and productivity of
$2.8 \mathrm{t} \mathrm{ha}^{-1}$ compared to China $\left(26 \mathrm{t} \mathrm{ha}^{-1}\right)(\mathrm{FAO}, 2002)$. In Odisha, it is cultivated in $11.01^{\prime} 000$ ha area, production $50.9^{\prime} 000 \mathrm{mt}$, productivity $4.52 \mathrm{t} \mathrm{ha}^{-1}$.

Bean otherwise called as "the meat of the poor" is an important nutrient supplement for the malnourished people of Odisha. Farmers cultivate beans of various shapes, sizes mostly as a cash crop. So superior varieties must be developed by selection among and within populations that have very rich variations in important agronomic traits. For selection to be effective, it is essential to assess the quantum of genetic variability, extent of heritability, genetic advance and nature of character association with respect to different characters. Keeping in view of the above facts, the present investigation was carried out to evaluate the french bean genotypes to know the genetic variability, heritability and genetic advance, besides the nature and degree of association among pod yield and its contributing traits. 


\section{Materials and Methods}

The experimental material consisted of 28 diverse released and pre-released lines obtained from five states of India. The trials were evaluated during two consecutive rabi seasons of 2011-12 and 2012-13 at four locations of district Nayagarh in Odisha. The district lies under East and South-Eastern Coastal plain zone having latitude of $20.13^{\circ} \mathrm{N}$ and longitude of $85.1^{\circ} \mathrm{E}$. The experiment was laid out in a randomized block design with three replications in each of the four environments over both the growing seasons. The seeds of each genotype were sown on 2 rows of $3 \mathrm{~m}$. long keeping plant to plant and row to row spacing of $15 \mathrm{~cm}$ and $50 \mathrm{~cm}$. apart respectively in the month of November. All the recommended packages of practices were followed during the crop season for raising a healthy crop. Harvesting of pods was done at tender stage in three pickings. Observations were recorded from five different plants for 13 different characters such as days to $50 \%$ flowering (number), days to $1^{\text {st }}$ green pod picking (number), plant height (cm.), number of primary branches plant ${ }^{-1}$ (number), number of secondary branches plant ${ }^{-1}$ (number), basal internodal length $(\mathrm{cm}$.$) , basal internodal diameter (\mathrm{cm}$.$) , green pod length (\mathrm{cm}$.$) ,$ green pod width $(\mathrm{cm}$.), green pod breadth $(\mathrm{cm}$.), number of pods plant ${ }^{-1}$, single pod weight (g.), pod yield plant ${ }^{-1}$ (g.) were recorded using standard procedures.

Data collected during the two growing seasons on these traits were pooled, and analysis of variance was done as suggested by Panse and Sukhatme (1985). Variability was estimated following Burton and DeVane (1953). Heritability and genetic advance were calculated according to Hanson et al. (1956) and Johnson et al. (1955), respectively. Correlations were undertaken as per the procedure suggested by Johnson et al. (1955); Al-Jibouri et al. (1958) along with path coefficient analysis by Dewey and Lu (1959).

\section{Results and Discussion}

\subsection{Genetic variability, heritability and genetic advance}

Analysis of variance revealed significant differences among the genotypes of french bean for all the studied traits except green pod width and green pod breadth. The mean values of 28 genotypes for thirteen morphological traits are given (Table 1). Estimates of range, PCV, GCV, heritability (broad sense) and genetic advance (GA) as percent of means are given (Table 2). Considerable variability was observed for all the traits under study as indicated by high range indicating enough scope for bringing about improvement in the desired direction. The value of PCV ranged from $10.31 \%$ in pod breadth to $66.80 \%$ in basal internodal length. Traits showing moderate PCV value (i.e., $10-20 \%$ ) were green pod breadth, days to $1^{\text {st }}$ green pod picking, days to $50 \%$ flowering, green pod length, number of primary branches plant ${ }^{-1}$ and green pod width. Similarly traits such as single pod weight, number of secondary branches plant $^{-1}$, basal internodal diameter, plant height, number of pods plant ${ }^{-1}$, green pod yield plant ${ }^{-1}$ and basal internodal length showed high PCV value (i.e. $>20 \%$ ) as indicated by Sivasubramanian and Menon (1973).

The highest GCV value was observed for the basal internodal length $(61.26 \%)$ followed by green pod yield plant ${ }^{-1}(39.80 \%)$ and number of green pods plant ${ }^{-1}(36.80 \%)$. There was close relationship between GCV and PCV for traits such as days to $50 \%$ flowering, days to $1^{\text {st }}$ green pod picking, plant height, number of primary branches plant ${ }^{-1}$, number of secondary branches plant ${ }^{-1}$, green pod length, green pod width and number of pods plant ${ }^{-1}$ indicating that these characters are mostly governed by genetic factors with minor environmental influence. This result is in line with the findings of Lal et al. (2005); Pan et al. (2004). This suggests that selection can be effective on the basis of phenotype alone with equal probability of success. However, for the trait pod yield plant ${ }^{-1}, \mathrm{PCV}$ values were quite higher than GCV indicating yield was highly influenced by environment; hence selection for this trait may not be effective.

The GCV together with heritability estimates would give reliable indication of the expected amount of improvement through selection and therefore estimation of heritability is necessary. The characters such as green pod length, basal internodal diameter, days to $1^{\text {st }}$ green pod picking, plant height, basal internodal length, green pod width, number of pods plant $^{-1}$, days to $50 \%$ flowering, number of secondary branches plant ${ }^{-1}$ showed very high amount of heritability. The results are in consonance with the findings obtained by Nimbalkar et al. (2002) for plant height, green pod length and number of pods plant ${ }^{-1}$ and Singh et al. (2000) for days to $50 \%$ flowering. Higher heritability value indicates lesser influence of environment, hence more desirable for improvement.

However, the estimates of heritability alone are not sufficient for predicting the effect of selection. Johnson et al. (1955) reported that the heritability estimate along with genetic advance is more useful than the heritability alone in predicting that resultant effect of selecting the best individual genotypes as it suggests the presence of additive effects (Panse and Sukhatme, 1985). The value of GA expressed as \% of mean ranged from green pod breadth (12.39) to basal intermodal length (98.89). The traits such as number of primary branches plant $^{-1}$, green pod length, single pod weight, green pod width, days to $50 \%$ flowering, basal internodal diameter, number of secondary branches plant ${ }^{-1}$, plant height, number of pods plant $^{-1}$, pod yield plant ${ }^{-1}$ and basal internodal length showed high genetic gain $(>20 \%)$. The results are in accordance with 


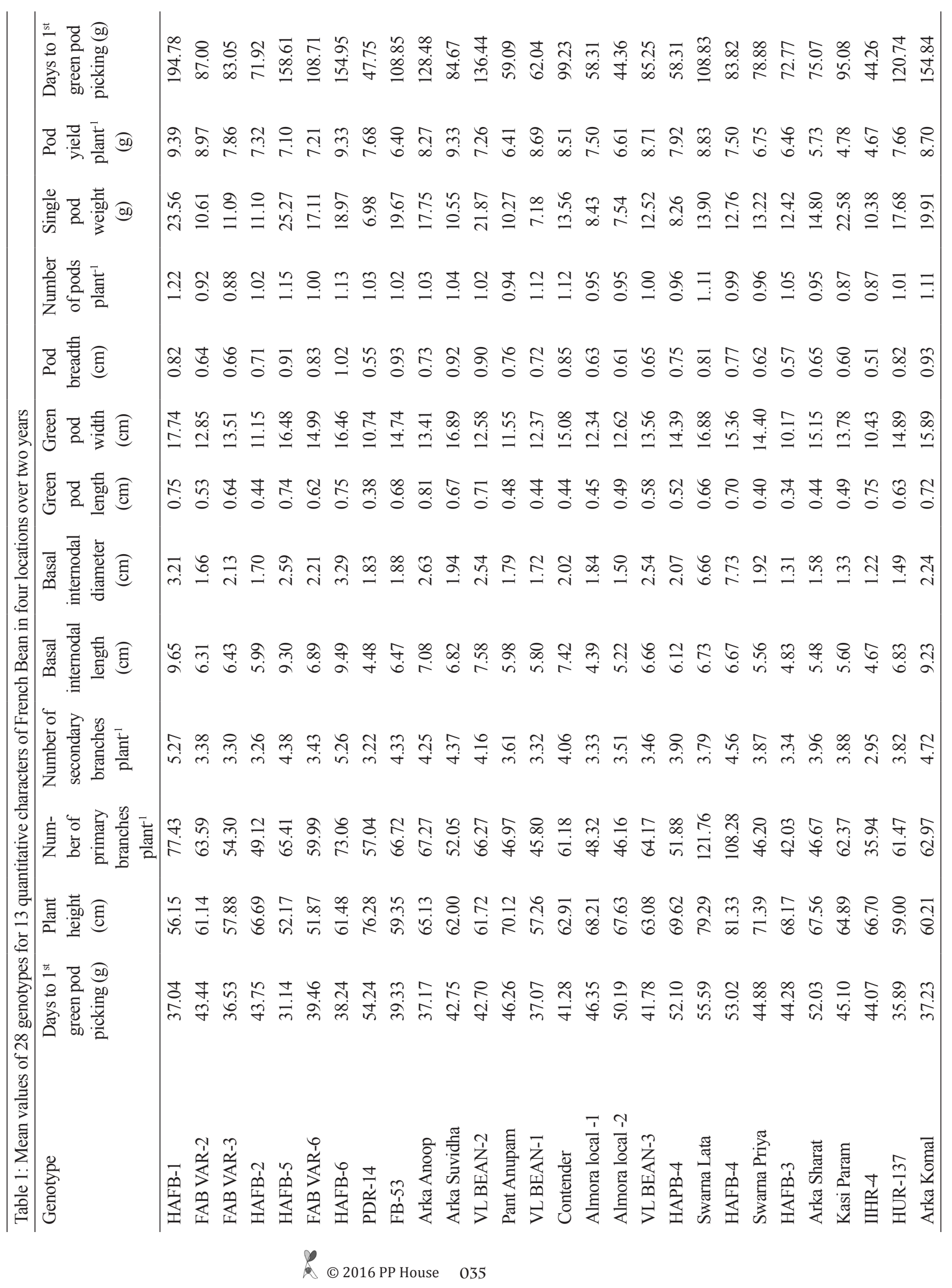




\begin{tabular}{|c|c|c|c|c|c|c|c|}
\hline Sl. no. & Characters & Range & Grand mean & GCV $(\%)$ & PCV $(\%)$ & $\mathrm{H}_{\mathrm{bs}}^{2}(\%)$ & GA as $\%$ of mean \\
\hline 01. & Days to $50 \%$ flowering & $31.14-55.59$ & 43.32 & 14.39 & 15.07 & 91.12 & 24.17 \\
\hline 02. & Days to $1^{\text {st }}$ green pod picking & $51.87-81.33$ & 64.62 & 11.07 & 11.91 & 86.42 & 18.11 \\
\hline 03. & Plant height & $35.94-121.76$ & 60.87 & 30.07 & 31.79 & 85.34 & 51.67 \\
\hline 04. & Number of primary branches plant ${ }^{-1}$ & $2.95-5.27$ & 3.88 & 15.12 & 18.17 & 69.21 & 22.13 \\
\hline 05. & Number of secondary branches plant $t^{-1}$ & $4.39-9.65$ & 6.56 & 22.11 & 23.05 & 92.00 & 37.32 \\
\hline 06. & Basal internodal length & $1.22-7.73$ & 2.38 & 61.26 & 66.80 & 84.12 & 98.89 \\
\hline 07. & Basal internodal diameter & $0.34-.81$ & 0.58 & 23.33 & 26.56 & 77.18 & 36.07 \\
\hline 08. & Green pod length & $10.17-17.74$ & 13.94 & 14.73 & 17.02 & 74.96 & 22.45 \\
\hline 09. & Green pod width & $0.51-1.02$ & 0.74 & 18.11 & 19.53 & 85.90 & 29.53 \\
\hline 10. & Green Pod breadth & $0.87-1.22$ & 1.02 & 8.52 & 10.31 & 68.26 & 12.39 \\
\hline 11. & Number of pods plant ${ }^{-1}$ & $6.98-25.27$ & 14.20 & 36.80 & 38.69 & 81.58 & 58.50 \\
\hline 12. & Single pod weight & $4.67-9.39$ & 7.56 & 16.46 & 21.17 & 60.44 & 22.52 \\
\hline 13. & Pod yield plant ${ }^{-1}$ & $44.26-194.78$ & 95.22 & 39.80 & 46.34 & 73.76 & 60.16 \\
\hline
\end{tabular}

the findings of Nimbalkar (2002); Rai et al. (2006).

In the experiment, high heritability coupled with high genetic advance over mean was recorded for the characters such as basal internodal length, number of pods plant ${ }^{-1}$, plant height, number of secondary branches plant ${ }^{-1}$, basal internodal diameter, green pod width, days to $50 \%$ flowering, number of primary branches plant ${ }^{-1}$, green pod length, single pod weight. Selection for these traits would be effective as they are likely to be controlled by additive gene effects (Panse and Sukhatme, 1985) and can be improved through selection, as these traits are less influenced by the environmental changes.

The results of simultaneous studies of coefficients of variation, heritability estimates and genetic gain at a glance revealed that in general the characters with high GCV also had high genetic gain. Further, heritability when considered in conjunctions with $\mathrm{GCV}$, and genetic advance also exhibited a similar pattern for some of the traits. Then selection for morphological traits like plant height $\left(\mathrm{GCV}=30.07, \mathrm{H}^{2}=85.34, \mathrm{GA} \%=51.67\right)$, number of pods plant ${ }^{-1}\left(\mathrm{GCV}=36.80, \mathrm{H}^{2}=81.58, \mathrm{GA} \%=58.50\right)$, number of secondary branches plant ${ }^{-1}\left(\mathrm{GCV}=22.11, \mathrm{H}^{2}=92.00\right.$, $\mathrm{GA} \%=37.32$ ) would be effective for improvement of yield in this population. Similar findings were reported by Rai et al. (2004); Kalia and Pathania (2007) for number of pods plant ${ }^{-1}$. Earlier Johnson et al. (1955) had also reported that high GCV along with high heritability and genetic advance were more effective for selection of soyabean genotypes, which was in agreement with these findings.

\subsection{Correlation}

In the present study, correlation coefficients between all possible pairs of thirteen quantitative characters are given
(Table 3). In general, the genotypic and phenotypic correlations showed similar trends but genotypic correlations $\left(\mathrm{r}_{\mathrm{g}}\right)$ were of higher magnitude than phenotypic correlations $\left(\mathrm{r}_{\mathrm{p}}\right)$, indicating the preponderance of genetic variance in expression of different characters and suggesting that there was a strong inherent association between the various characters studied. The strong positive association of characters with pod yield plant ${ }^{-1}$ may be attributed to linkage and pleiotropy as reported by Wigan and Mather (1942); Sprague (1966).

However, very close values of genotypic and phenotypic correlations were also observed between some character combinations which might be due to reduction in error (environmental) variance to minor proportions as reported by Dewey and Lu (1959) in Wheat grass.

The pod yield plant ${ }^{-1}$ was positively and significantly correlated (genotypic and phenotypic) with number of pods plant ${ }^{-1}$ $(0.92,0.83)$, green pod length $(0.89 .0 .78)$, number of secondary branches plant ${ }^{-1}(0.86,0.77)$, number of primary branches plant ${ }^{-1}$ $(0.83,0.56)$, basal internodal diameter $(0.68,0.51)$, green pod width $(0.78,0.73)$, green pod breadth $(0.69,0.50)$, plant height $(0.47,0.40)$ indicating the importance of these characters for yield improvement (Table 2). Similar observations were reported by Verma et al. (2014). The higher magnitude of positive and significant association of number of green pods plant $^{-1}$, green pod length with yield suggested that these characters were the principal yield contributor and indicated their importance as yield components in influencing the yield of the plant. Therefore, selection of plant types with higher number of green pods plant ${ }^{-1}$ and green pod length would necessarily lead to higher pod yield plant ${ }^{-1}$. Similar observations were reported by Singh et al. (2011). Pod yield plant ${ }^{-1}$ was negatively and significantly correlated (at both levels) with days to 50 


\begin{tabular}{|c|c|c|c|c|c|c|c|c|c|c|c|c|c|}
\hline Characters & $\mathrm{r}_{\mathrm{g}} / \mathrm{r}_{\mathrm{p}}$ & $\begin{array}{l}\text { Days to } 1^{\text {st }} \\
\text { green pod } \\
\text { picking } \\
\text { (g) }\end{array}$ & $\begin{array}{l}\text { Plant } \\
\text { height } \\
(\mathrm{cm})\end{array}$ & $\begin{array}{c}\text { Num- } \\
\text { ber of } \\
\text { primary } \\
\text { branches } \\
\text { plant }^{-1}\end{array}$ & $\begin{array}{l}\text { Number } \\
\text { of sec- } \\
\text { ondary } \\
\text { branches } \\
\text { plant }^{-1}\end{array}$ & $\begin{array}{c}\text { Basal in- } \\
\text { ternodal } \\
\text { length } \\
(\mathrm{cm})\end{array}$ & $\begin{array}{c}\text { Basal } \\
\text { internodal } \\
\text { diameter } \\
(\mathrm{cm})\end{array}$ & $\begin{array}{l}\text { Green } \\
\text { pod } \\
\text { length } \\
(\mathrm{cm})\end{array}$ & $\begin{array}{l}\text { Green } \\
\text { pod } \\
\text { width } \\
(\mathrm{cm})\end{array}$ & $\begin{array}{c}\text { Pod } \\
\text { breadth } \\
(\mathrm{cm})\end{array}$ & $\begin{array}{c}\text { Number } \\
\text { of pods } \\
\text { plant }^{-1}\end{array}$ & $\begin{array}{l}\text { Single } \\
\text { pod } \\
\text { weight } \\
(\mathrm{g})\end{array}$ & $\begin{array}{c}\text { Pod } \\
\text { yield } \\
\text { plant }^{-1} \\
(\mathrm{~g})\end{array}$ \\
\hline Days to & $r_{g}$ & $0.88^{* *}$ & 0.18 & -0.29 & $-0.59^{* *}$ & 0.31 & $-0.44^{*}$ & -0.22 & $-0.44^{*}$ & -0.36 & $-0.54^{* *}$ & -0.24 & $-0.61^{* * *}$ \\
\hline $\begin{array}{l}50 \% \\
\text { flowering }\end{array}$ & $r_{p}$ & $0.78^{* *}$ & 0.16 & -0.22 & $-0.54^{* *}$ & 0.27 & -0.36 & -0.18 & $-0.39^{*}$ & -0.28 & $-0.46^{*}$ & -0.18 & $-0.50^{* *}$ \\
\hline Days to $1^{\text {st }}$ & $r_{g}$ & & 0.29 & -0.18 & $-0.50^{* *}$ & $0.46^{*}$ & -0.32 & -0.25 & $-0.41^{*}$ & -0.26 & $-0.48^{* *}$ & -0.17 & $-0.51^{* *}$ \\
\hline $\begin{array}{l}\text { green pod } \\
\text { picking }\end{array}$ & $r_{p}$ & & 0.26 & -0.13 & $-0.45^{*}$ & $0.40^{*}$ & -0.27 & -0.21 & -0.35 & -0.21 & $-0.40^{*}$ & -0.13 & $-0.42^{*}$ \\
\hline \multirow{2}{*}{$\begin{array}{l}\text { Plant } \\
\text { height }\end{array}$} & $r_{g}$ & & & $0.48^{* *}$ & $0.44^{*}$ & $0.81^{* *}$ & $0.48^{* *}$ & $0.58^{* *}$ & $0.42^{*}$ & $0.40^{*}$ & 0.35 & $0.41^{*}$ & $0.47^{*}$ \\
\hline & $r_{p}$ & & & $0.39^{*}$ & $0.42 *$ & $0.72^{* *}$ & $0.41^{*}$ & $0.49^{* *}$ & $0.38^{*}$ & 0.33 & 0.31 & 0.30 & $0.40^{*}$ \\
\hline \multirow{2}{*}{$\begin{array}{l}\text { Number } \\
\text { of primary } \\
\text { branches } \\
\text { plant }^{-1}\end{array}$} & $r_{g}$ & & & & $0.83^{* *}$ & $0.40^{*}$ & $0.59^{* *}$ & $0.80^{* *}$ & $0.77^{* *}$ & $0.62^{* *}$ & $0.69^{* *}$ & $0.42^{*}$ & $0.83^{* *}$ \\
\hline & $r_{p}$ & & & & $0.67^{* *}$ & 0.31 & $0.44^{*}$ & $0.59^{* *}$ & $0.60^{* *}$ & $0.42^{*}$ & $0.51^{* *}$ & 0.23 & $0.56^{* *}$ \\
\hline \multirow{2}{*}{$\begin{array}{l}\text { Number of } \\
\text { secondary } \\
\text { branches } \\
\text { plant }^{-1}\end{array}$} & $\mathrm{r}_{\mathrm{g}}$ & & & & & 0.31 & $0.69^{* *}$ & $0.75^{* *}$ & $0.82^{* *}$ & $0.70^{* *}$ & $0.72^{* *}$ & $0.57^{* *}$ & $0.86^{* *}$ \\
\hline & $r_{p}$ & & & & & 0.27 & $0.57^{* *}$ & $0.61^{* *}$ & $0.72^{* *}$ & $0.58^{* *}$ & $0.63^{* *}$ & $0.42^{*}$ & $0.77^{* *}$ \\
\hline \multirow{2}{*}{$\begin{array}{l}\text { Basal } \\
\text { internodal } \\
\text { length }\end{array}$} & $r_{g}$ & & & & & & $0.41^{*}$ & $0.47^{*}$ & 0.30 & 0.31 & 0.12 & 0.34 & 0.27 \\
\hline & $r_{p}$ & & & & & & 0.33 & 0.37 & 0.25 & 0.24 & 0.10 & 0.22 & 0.20 \\
\hline \multirow{2}{*}{$\begin{array}{l}\text { Basal } \\
\text { internodal } \\
\text { diameter }\end{array}$} & $\mathrm{r}_{\mathrm{g}}$ & & & & & & & $0.54^{* *}$ & $0.58^{* *}$ & 0.28 & $0.58^{* *}$ & 0.27 & $0.68^{* *}$ \\
\hline & $r_{p}$ & & & & & & & $0.39^{*}$ & $0.50^{* *}$ & 0.20 & $0.45^{*}$ & 0.18 & $0.51^{* *}$ \\
\hline \multirow{2}{*}{$\begin{array}{l}\text { Green pod } \\
\text { length }\end{array}$} & $\mathrm{r}_{\mathrm{g}}$ & & & & & & & & $0.72^{* *}$ & $0.53^{* *}$ & $0.56^{* *}$ & $0.49^{* *}$ & $0.89^{* *}$ \\
\hline & $r_{p}$ & & & & & & & & $0.57^{* *}$ & $0.38^{*}$ & $0.42^{*}$ & 0.34 & $0.78^{* *}$ \\
\hline \multirow{2}{*}{$\begin{array}{l}\text { Green pod } \\
\text { width }\end{array}$} & $r_{g}$ & & & & & & & & & $0.64^{* *}$ & $0.56^{* *}$ & $0.51^{* *}$ & $0.73^{* *}$ \\
\hline & $\mathrm{r}_{\mathrm{p}}$ & & & & & & & & & $0.49^{* *}$ & $0.46^{*}$ & $0.39^{*}$ & $0.58^{* *}$ \\
\hline \multirow{2}{*}{$\begin{array}{l}\text { Pod } \\
\text { breadth }\end{array}$} & $r_{g}$ & & & & & & & & & & $0.41^{*}$ & $0.65^{* *}$ & $0.69^{* *}$ \\
\hline & $r_{p}$ & & & & & & & & & & 0.32 & $0.41^{*}$ & $0.50^{* *}$ \\
\hline \multirow{2}{*}{$\begin{array}{l}\text { Number } \\
\text { of pods } \\
\text { plant }^{-1}\end{array}$} & $\mathrm{r}_{\mathrm{g}}$ & & & & & & & & & & & -0.03 & $0.92^{* *}$ \\
\hline & $r_{p}$ & & & & & & & & & & & 0.10 & $0.83^{* *}$ \\
\hline \multirow{2}{*}{$\begin{array}{l}\text { Single pod } \\
\text { weight }\end{array}$} & $r_{g}$ & & & & & & & & & & & & $0.41^{*}$ \\
\hline & $r_{p}$ & & & & & & & & & & & & $0.46^{*}$ \\
\hline \multicolumn{14}{|c|}{${ }^{*} p<0.05 ;{ }^{* *} p<0.01$} \\
\hline
\end{tabular}

flowering and days to $1^{\text {st }}$ green pod picking indicating some possibility of improving yield with early maturity type. Similar findings were reported by Dubey et al. (2009).

\subsection{Path coefficient analysis}

Number of pods plant ${ }^{-1}$ showed the highest positive direct effect followed by green pod length, number of primary branches plant $^{-1}$, number of secondary branches plant ${ }^{-1}$, plant height, single pod weight, green pod breadth in that order (Table
4). Similar results were reported by Rai et al. (2010). But the main effects of the trait such as days to $50 \%$ flowering is significant negative and resulted mainly due to the negative direct effect of the character itself besides the negative indirect effect via number of secondary branches plant ${ }^{-1}$, days to $1^{\text {st }}$ green pod picking. Similar is the case for days to $1^{\text {st }}$ green pod picking. In case of basal internodal diameter, the correlation (significant and positive) is due to indirect effect through 


\begin{tabular}{|c|c|c|c|c|c|c|c|c|c|c|c|c|c|}
\hline \multirow[t]{2}{*}{ Effect of characters } & \multicolumn{12}{|c|}{ Effect via } & \multirow{2}{*}{$\begin{array}{l}\text { Correlation } \\
\text { with Pod } \\
\text { yield plant }{ }^{-1} \\
\text { (g) }\end{array}$} \\
\hline & $\begin{array}{c}\text { DGPP } \\
\text { (g) }\end{array}$ & $\begin{array}{l}\mathrm{PH} \\
(\mathrm{cm})\end{array}$ & $\begin{array}{l}\text { NPB } \\
\text { plant }^{-1}\end{array}$ & $\begin{array}{l}\text { NSB } \\
\text { plant }^{-1}\end{array}$ & $\begin{array}{l}\text { BIL } \\
(\mathrm{cm})\end{array}$ & $\begin{array}{l}\text { BID } \\
(\mathrm{cm})\end{array}$ & $\begin{array}{l}\text { GPL } \\
(\mathrm{cm})\end{array}$ & $\begin{array}{l}\text { GPW } \\
(\mathrm{cm})\end{array}$ & $\begin{array}{l}\text { PB } \\
(\mathrm{cm})\end{array}$ & $\begin{array}{c}\mathrm{NP} \\
\text { plant }^{-1}\end{array}$ & $\begin{array}{c}\text { SPW } \\
\text { (g) }\end{array}$ & $\begin{array}{c}\text { DGPP } \\
\text { (g) }\end{array}$ & \\
\hline $\begin{array}{l}\text { Days to } 50 \% \\
\text { flowering }\end{array}$ & -0.31 & -0.29 & 0.23 & -0.23 & -0.45 & -0.30 & 0.00 & 0.04 & 0.16 & -0.09 & 0.43 & 0.17 & $-0.61^{* *}$ \\
\hline Days to $1^{\text {st }}$ green pod picking & -0.27 & -0.33 & 0.43 & -0.15 & -0.39 & -0.44 & 0.00 & 0.04 & 0.15 & -0.07 & 0.39 & 0.13 & $-0.51^{* *}$ \\
\hline Plant height & -0.05 & -0.09 & 0.50 & 0.59 & 0.64 & -0.37 & -0.01 & -0.10 & -0.15 & 0.10 & -0.28 & -0.30 & $0.47^{*}$ \\
\hline $\begin{array}{l}\text { Number of primary branches } \\
\text { plant }^{-1}\end{array}$ & 0.09 & 0.06 & 0.73 & 0.81 & 0.64 & -0.38 & -0.01 & -0.14 & -0.28 & 0.17 & -0.55 & -0.31 & $0.83^{* *}$ \\
\hline $\begin{array}{l}\text { Number of secondary } \\
\text { branches plant }{ }^{1}\end{array}$ & 0.18 & 0.17 & 0.67 & 0.68 & 0.69 & -0.30 & -0.01 & -0.13 & -0.30 & 0.19 & -0.58 & -0.41 & $0.86^{* *}$ \\
\hline Basal internodal length & -0.09 & -0.15 & 0.38 & 0.83 & 0.74 & -0.95 & -0.01 & -0.08 & -0.11 & 0.08 & -0.10 & -0.08 & 0.27 \\
\hline Basal internodal diameter & 0.14 & 0.10 & 0.73 & 0.48 & 0.53 & -0.40 & -0.01 & -0.09 & -0.21 & 0.07 & -0.47 & -0.19 & $0.68^{* *}$ \\
\hline Green pod length & 0.07 & 0.08 & 0.65 & -0.17 & 0.63 & -0.45 & -0.01 & 0.83 & -0.26 & 0.32 & -0.45 & -0.35 & $0.89^{* *}$ \\
\hline Green pod width & 0.14 & 0.13 & 0.63 & 0.62 & 0.63 & -0.29 & -0.01 & -0.12 & -0.36 & 0.17 & -0.45 & -0.37 & $0.73^{* *}$ \\
\hline Pod breadth & 0.11 & 0.08 & 0.60 & 0.51 & 0.54 & -0.30 & -0.01 & -0.09 & -0.23 & 0.27 & -0.33 & -0.47 & $0.69^{* *}$ \\
\hline Number of pods plant ${ }^{-1}$ & 0.17 & 0.16 & -0.53 & -0.56 & 0.56 & -0.12 & -0.05 & -0.09 & -0.20 & 0.11 & 0.88 & 0.50 & $0.92^{* *}$ \\
\hline Single pod weight & 0.07 & 0.06 & 0.62 & 0.34 & -0.72 & -0.33 & -0.01 & -0.08 & -0.18 & 0.17 & 0.02 & 0.43 & $0.41^{*}$ \\
\hline
\end{tabular}

DGPP: Days to $1^{\text {st }}$ green pod picking (g); PH: Plant height; NPB: Number of primary branches plant ${ }^{1}$; NSB: Number of secondary branches; BIL: Basal internodal length; BID: Basal internodal diameter; GPL: Green pod length; GPW: Green pod width; PB: Pod breadth; NP: Number of pods; SPW: Single pod weight

plant height, number of secondary branches plant ${ }^{-1}$. So, for the characters like basal internodal diameter, the indirect causal factors (mentioned above) are to be considered simultaneously for selection, since indirect effects seem to be the cause of correlation. Since the correlation coefficient between number of pods plant ${ }^{-1}$ and pod yield was almost equal to its direct effect, so the correlation explains true relationship and a direct selection through this trait would be effective. In the present experiment, the contribution of residual accounted for the characters not studied was negligible (0.03).

\section{Conclusion}

The analysis showed that out of 13 characters so far studied, three traits i.e. number of pods plant ${ }^{-1}$, plant height and number of secondary branches per plant showed high variability, heritability, genetic advance besides high correlation and path coefficient values with pod yield per plant. So these traits should be given due consideration during selection process for development of superior genotypes with high pod yield.

\section{References}

Al-Jibouri, H.A., Miller, P.A., Robinson, H.F., 1958. Genotypic and environmental variances and covariances in an upland cotton cross of interspecific origin. Agronomy
Journal 50, 633-636.

Burton, G.W., DeVane, E.W., 1953. Estimating heritability in tall fescue (Festuca arundinacea) from replicated clonal material. Agronomy Journal 45, 468-471.

Dewey, D.R., Lu, K.H., 1959. A correlation and path analysis of components of crested wheat grass seed production. Agronomy Journal 51, 515-518.

Dubey, A.K., Singh, N.P., Srivastav, J.P., 2009. Character association and coefficient analysis in french bean. Vegetable Science 36(3), 378-379.

FAO, 2002. FAO Bulletin of statistics, Food and Agricultural Organisation of the United Nations, Rome 3(2), 104.

FAOSTAT, 2008. Food and Agricultural Organisation Statistics. Available from http://www.faostat.org.

Hanson, C.H., Robinson, H.F.,Comstock, R.E., 1956. Biometrical studies of yield in segregating population of Korean lespedeza. Agronomy Journal 47, 268-272.

Johnson, H.W., Robinson, H.F., Comstock, R.E., 1955. Genotypic and phenotypic correlations in soybean and their implications in selection. Agronomy Journal 47, 477-483.

Kalia, P., Pathania, N.K., 2007. Genetic variability and trait relationships for quantitative and quality characters in winter bean (Vicia faba L.). Acta Horticulturae 752, 405-409.

Kaplan, L., 1965. Archaeology and domestication in America 
Phaseolus bean. Economic Botany 19, 358.

Lal, H., Rai, M., Verma, A.,Vishwanath., 2005. Analysis of genetic divergence of dolichos bean (Lablab purpureus) genotypes. Vegetable science 32(2), 129-132.

NHB, 2012. NHB Database, 2011-12. Available from http:// www.nhb.gov.in.

Nimbalkar, C.A., Baviskar, A.P., Desai, U.T., 2002. Selection strategy for yield improvement in rajmash (Phaseolus vulgaris L.). Indian Journal of Genetics and Plant Breeding 62(4), 349-351.

Pan, R.S., Singh, A.K., Rai, M., Krishna Prasad, V.S.R., Kumar, S., 2004. Genetic variation and character association in photo-insensitive dolichos bean (Lablab purpureus L. Sweet). Vegetable Science 31(1), 22-25.

Panse, V.G., Sukhatme, P.V., 1985. Statistical methods for agricultural workers. ( $4^{\text {th }}$ Edn.), ICAR, New Delhi, 389

Rai, N., Asati, B.S., Yadav, D.S., Singh, A.K., 2004. Genetic analysis in French bean (P. vulgaris L.).Vegetable Science 31(2), 138-141.

Rai, N., Asati, B.S., Singh, A.K., Yadav, D.S., 2006. Genetic variability, character association and path coefficient study in pole type French bean. Indian Journal of Horticulture 63(2), 188-191.

Rai, N., Singh, P.K., Verma, A., Yadav, P.K.,Choubey, T., 2010. Hierarchical analysis for genetic variability in pole type french bean. Indian Journal of Horticulture 67 (Special Issue), 150-153.
Singh, S.P., 1999. Improvement of small-seeded race Mesoamerican cultivars. In: Singh, S.P., Kluwer, D., Common Bean Improvement in the Twenty-first Century, 225-274.

Singh, B.K., Singh, B.P., Ram, H.H., 2000. Variability and correlation studies in bush type french bean (Phaseolus vulgaris L.) in relation to green pod yield. Progressive Horticulture 32(2), 176-182.

Singh, D.N., Sivakumar, R., Bhanja, P.K., 2011. Variability and character association in new genotypes of french bean. Environment and Ecology 29(4), 1811-1813.

Sivasubramanian, S., Menon, M., 1973. Heterosis and inbreeding depression in rice. Madras Agricultural Journal 60, 1139.

Sprague, G.F., 1966. Quantitative genetics in plant improvement in plant breeding. In: Frey, K.J. (Edn.), Iowa State University Press, Ames, Iowa, 315-354.

Verma, V.K., Jha, A.K., Pandey, A., Kumar, A., Chowdhury, P., Swer, T.L., 2014. Genetic divergence, path coefficient and cluster analysis of french bean (Phaseolus vulgaris) genotypes. Indian Journal of Agricultural Sciences 84(8), 925-930.

Wigan, L.G., Mather, K., 1942. Correlated response to the selection of polygenic characters. Annals of Eugenics II, 354-364. 